\title{
Peningkatan Hasil Belajar Materi Memahami Teknik Melempar Bola Melalui Penerapan Model Kooperatif Tipe Snowball Throwing
}

\author{
Abdul Qowi \\ SDN Wonokusumo IV/43 Surabaya \\ Jl. Wonokusumo Tengah No. 4, Wonokusumo, Kec. Semampir, Kota Surabaya, Jawa Timur \\ abdul.qowi65@gmail.com
}

\begin{abstract}
After a year and a half of online learning due to the Covid-19 pandemic, face-to-face learning is limited to taking into account strict health procedures. Limited face-to-face learning (PTMT) is not necessarily the same as faceto-face learning before the Covid-19 pandemic occurred, because it contains elements that collaborate face-toface learning with online learning, which in contemporary terms is called hybrid learning. Therefore, the intensification of face-to-face learning activities is a determinant of learning success so that the learning outcomes obtained by students can be maximized. The purpose of this study was to determine whether or not there was an increase in learning outcomes in Understanding Ball Throwing Techniques through the application of the Snowball Throwing Cooperative model in grade 3-A students of SD Negeri Wonokusumo IV/43 Surabaya. This research was conducted at SD Negeri Wonokusumo IV/43, Semampir sub-district, Surabaya City with a two-cycle action research mechanism. Based on data analysis, from this study it can be concluded that there is an increase in learning outcomes in Understanding Ball Throwing Techniques through the application of the Snowball Throwing Cooperative model in grade 3-A students of SD Negeri Wonokusumo IV/43 Surabaya.
\end{abstract}

Keywords: Ball Throwing Technique, Cooperative Model, Snowball Throwing Type.

\begin{abstract}
Abstrak
Setelah satu setengah tahun menjalani pembelajaran secara daring akibat adanya pandemi Covid-19, maka secara terbatas dilaksanakan pembelajaran tatap muka dengan tetap memperhatikan prosedur kesehatan yang ketat. Pembelajaran tatap muka terbatas (PTMT) ini tidak serta merta sama dengan pembelajaran tatap muka sebelum pandemi Covid-19 terjadi, karena di dalamnya terdapat unsur yang mengkolaborasikan pembelajaran secara tatap muka dengan pembelajaran secara daring, yang dalam istilah kekiniannya disebut pembelajaran hybrid. Oleh karenanya intensifikasi kegiatan pembelajaran secara tatap muka menjadi penentu keberhasilan pembelajaran agar hasil belajar yang diperoleh siswa dapat maksimal. Tujuan penelitian ini adalah untuk mengetahui ada tidaknya dan seberapa besar peningkatan hasil belajar Materi Memahami Teknik Melempar Bola melalui penerapan model Kooperatif tipe Snowball Throwing pada siswa kelas 3-A SD Negeri Wonokusumo IV/43 Surabaya. Penelitian ini dilaksanakan di SD Negeri Wonokusumo IV/43 kecamatan Semampir Kota Surabaya dengan mekanisme penelitian tindakan dua siklus. Berdasarkan analisis data, dari penelitian ini dapat ditarik kesimpulan bahwa ada peningkatan hasil belajar Materi Memahami Teknik Melempar Bola melalui penerapan model Kooperatif tipe Snowball Throwing pada siswa kelas 3-A SD Negeri Wonokusumo IV/43 Surabaya.
\end{abstract}

Kata kunci: Teknik Melempar Bola, Model Kooperatif, Tipe Snowball Throwing

Copyright (c) 2021 Abdul Qowi

Corresponding author: Abdul Qowi

Email Address: abdul.qowi65@gmail.com (Jl. Wonokusumo Tengah No. 4, Kec. Semampir, Kota Surabaya)

Received 09 September 2021, Accepted 06 October 2021, Published 10 November 2021

\section{PENDAHULUAN}

Makna dan hakikat belajar diartikan sebagai proses membangun makna/ pemahaman terhadap informasi dan/atau pengalaman. Proses membangun makna tersebut dapat dilakukan sendiri oleh siswa atau bersama orang lain. Proses itu disaring dengan persepsi, pikiran (pengetahuan awal), dan perasaan siswa (Sidi, 2004:4). Belajar bukanlah proses menyerap pengetahuan yang sudah jadi bentukan guru. Buktinya, hasil ulangan siswa berbeda-beda padahal mendapat pengajaran yang sama, dari guru yang 
sama, dan pada saat yang sama. Pembelajaran yang bermakna akan membawa siswa pada pengalaman belajar yang mengesankan. Pengalaman yang diperoleh siswa akan semakin berkesan apabila proses pembelajaran yang diperolehnya merupakan hasil dari pemahaman dan penemuannya sendiri. Dalam konteks ini siswa mengalami dan melakukannya sendiri. Proses pembelajaran yang berlangsung melibatkan siswa sepenuhnya untuk merumuskan sendiri suatu konsep. Keterlibatan guru hanya sebagai fasilitator dan moderator dalam proses pembelajaran tersebut.

Menurut Kurikulum Tingkat Satuan Pendidikan (KTSP) yang disempurnakan dalam Kurikulum 2013, bahwa setiap individu mempunyai potensi yang harus dikembangkan, maka proses pembelajaran yang cocok adalah yang menggali potensi anak untuk selalu kreatif dan berkembang.

Namun kenyataan di lapangan belum menunjukkan ke arah pembelajaran yang bermakna. Para pendidik masih perlu penyesuaian dengan Kurikulum 2013, para guru sendiri belum siap dengan kondisi yang sedemikian plural sehingga untuk mendesain pembelajaran yang bermakna masih kesulitan. Sistem pembelajaran duduk tenang, mendengarkan informasi dari guru sepertinya sudah membudaya sejak dulu, sehingga untuk mengadakan perubahan ke arah pembelajaran yang aktif, kreatif, menyenangkan agak sulit.

Berdasarkan pengamatan terhadap proses pembelajaran PJOK diperoleh informasi bahwa selama proses pembelajaran, guru belum memberdayakan seluruh potensi dirinya sehingga sebagian besar siswa belum mampu mencapai kompetensi individual yang diperlukan untuk mengikuti pelajaran lanjutan. Beberapa siswa belum belajar sampai pada tingkat pemahaman. Siswa baru mampu menghafal fakta, konsep, prinsip, hukum, teori, dan gagasan inovatif lainnya pada tingkat ingatan, mereka belum dapat menggunakan dan menerapkannya secara efektif dalam pemecahan masalah sehari-hari yang kontekstual.

Pembelajaran Pendidikan Jasmani, Olahraga dan Kesehatan (PJOK) juga tidak luput dari kecenderungan proses pembelajaran teacher centered. Kondisi demikian tentu membuat proses pembelajaran hanya dikuasai guru. Apalagi pembelajaran PJOK merupakan mata pelajaran sarat materi sehingga siswa dituntut memiliki pemahaman yang holistik terhadap materi yang disampaikan guru. Terkait belum optimalnya hasil belajar materi memahami teknik melempar bola, yaitu pada materi Memahami Teknik Melempar Bola, maka penulis berupaya untuk menerapkan model pembelajaran Snowball Throwing sebagai salah satu alternatif pembelajaran bermakna yang bermuara pada pembelajaran yang aktif, kreatif, efektif, dan menyenangkan.

Tujuan penelitian ini adalah (1) untuk mengetahui ada tidaknya peningkatan hasil belajar materi memahami teknik melempar bola melalui penerapan model Kooperatif tipe Snowball Throwing pada siswa kelas 3-A SD Negeri Wonokusumo IV/43 Surabaya, dan (2) untuk mengetahui seberapa besar peningkatan hasil belajar Materi Memahami Teknik Melempar Bola melalui penerapan model Kooperatif tipe Snowball Throwing pada siswa kelas 3-A SD Negeri Wonokusumo IV/43 Surabaya. 


\section{Pendidikan Jasmani, Olahraga dan Kesehatan (PJOK)}

Pendidikan Jasmani adalah suatu proses pembelajaran melalui aktivitas jasmani yang didesain untuk meningkatkan kebugaran jasmani, mengembangkan keterampilan motorik, pengetahuan dan perilaku hidup sehat dan aktif, sikap sportif, dan kecerdasan emosi. Lingkungan belajar diatur secara seksama untuk meningkatkan pertumbuhan dan perkembangan seluruh ranah, yaitu jasmani, psikomotor, kognitif dan afektif.

Materi mata pelajaran pendidikan jasmani yang meliputi pengalaman mempraktikkan keterampilan dasar permainan dan olahraga, aktivitas pengembangan, uji diri, aktivitas ritmik, akuatik (aktivitas air) dan pendidikan luar kelas (Outdoor education). Materi-materi semacam ini disajikan untuk membantu siswa agar memahami mengapa manusia bergerak dan bagaimana cara melakukan gerakan secara aman, efisien dan efektif. Adapun implementasinya perlu dilakukan secara terencana, bertahap dan berkelanjutan yang pada gilirannya siswa diharapkan dapat meningkatkan sikap positif bagi diri sendiri dan menghargai manfaat aktivitas jasmani.

Berdasarkan konsep learning by moving, pendidikan jasmani memiliki tujuan dan fungsi yang tentunya berbeda dengan ilmu pengetahuan yang lain. Adapaun tujuan pendidikan jasmani adalah sebagai berikut:

1. Meletakkan landasan karakter yang kuat melalui internalisasi nilai dalam pendidikan jasmani

2. Membangun landasan kepribadian yang kuat, sikap cinta damai, sikap sosial dan toleransi dalam konteks kemajemukan budaya, etnis dan agama

3. Menumbuhkan kemampuan berfikir kritis melalui tugas-tugas pembelajaran Pendidikan Jasmani

4. Mengembangkan sikap sportif, jujur, disiplin, bertanggung jawab, kerjasama, percaya diri, dan demokratis melalui aktivitas jasmani

5. Mengembangkan keterampilan gerak dan keterampilan teknik serta strategi berbagai permainan dan olahraga, aktivitas pengembangan, senam, aktivitas ritmik, akuatik (aktivitas air) dan pendidikan luar kelas (Outdoor education)

6. Mengembangkan keterampilan pengelolaan diri dalam upaya pengembangan dan pemeliharaan kebugaran jasmani serta pola hidup sehat melalui berbagai aktivitas jasmani

7. Mengembangkan keterampilan untuk menjaga keselamatan diri sendiri dan orang lain

8. Mengetahui dan memahami konsep aktivitas jasmani sebagai informasi untuk mencapai kesehatan, kebugaran dan pola hidup sehat

9. Mampu mengisi waktu luang dengan aktivitas jasmani yang bersifat rekreatif

\section{Permainan Melempar}

Olahraga sepertinya tetap menjadi pilhan terbaik nan harus dilakukan bila kita ingin memiliki tubuh nan sehat. Sepertinya olahraga nan paling sederhana, murah, dan dapat dilakukan oleh siapa pun salah satunya ialah lari. Lari termasuk dalam cabang cabang atletik. Cabang-cabang atletik meliputi olahraga lari, lompat, dan lempar. Atletik merupakan cabang olahraga nan telah diperlombakan sejak olimpiade pertama dilaksanakan pada 776 SM lalu. 
Mengingat zaman dahulu masih belum banyak terdapat beberapa fasilitas olahraga, tampaknya menjadi hal nan sangat wajar bila cabang cabang atletik menjadi satu-satunya jenis olahraga nan diperlombakan pada saat pertama kali olimpiade digelar. Pada saat dikenalkan pertama kali di kejuaraan olimpiade, Bangsa Yunani membuat semacam pembagian kategori perlombaan. Kategori perlombaan nan memfokuskan pada olahraga lari dan melempar ialah Roman Game. Ketegori ini syahdan berakar dari Yunani murni.

Perlombaan olahraga ini rupanya sangat digemari oleh anak-anak bangsawan pada masa itu. Mereka pun kemudian dilatih berlari, bertarung, bergulat, berkuda, memanah, dan latihan menggunakan senjata. Beberapa pertandingan pun sering digelar antara mereka. Ketika seseorang ingin menggeluti cabang cabang atletik maka secara langsung orang itu harus dapat berlari lebih cepat, melompat jauh lebih tinggi, dan melempar lebih jauh. Jika tidak, maka akan bisa dipastikan dia akan selalu kalah dalam setiap perlombaan atletik. Salah satu cabang cabang atletik yaitu cabang atletik lempar. Cabang atletik lempar dilakukan di arena lapangan, sama dengan cabang cabang atletik lompat. Cabang ini mempunyai empat cabang nan dilombakan, di antaranya:

1. Tolak peluru, cabang olahraga ini dilakukan dengan cara melemparkan bola besi nan sangat berat (peluru) sejauh mungkin. Tolak Peluru merupakan suatu aktivitas yg dilakukan utk mencapai lemparan atau tolakan yg sejauh-jauhnya. Peluru nan digunakan terbuat dari besi berbentuk bulat telur dengan berat $3 \mathrm{~kg}, 4 \mathrm{~kg}, 5 \mathrm{~kg}, 7 \mathrm{~kg}$. dengan ruang lingkaran lebar $5 \times 3$ meter. Yang terpenting dari Tolak peluru ialah peluru harus didorong keluar dengan kecepatan maksimal, dengan sudut kira-kira 40 derajat. Posisi buat menolak harus ditekankan pada kaki. sebab kaki ialah bagian nan terkuat dari badan.

2. Lempar peluru, kurang lebih sama dengan nan dilakukan pada tolak peluru.

3. Lempar lembing, nan harus dilemparkan sejauh mungkin dalam olahraga ini ialah lembing (sejenis tombak). Lembing dipegang pada bagian pegangannya nan diikat dengan tali sepanjang $20 \mathrm{~cm}$, dengan jari kelingking terdekat pada ujung lembing, sedangkan ibu jari dan telunjuk atau telunjuk dan jari tengah memegang erat ikatan tali pegangan nan berbentuk tonjolan. Pegangan itu harus kuat dan jari-jari lainya menahan lembing di atas telapak tangan. Telapak tangan harus tetap menghadap ke atas selama gerakan melempar.

4. Lempar cakram, buat cabang ini, benda nan dilemparkan ialah cakram. Bentuknya kurang lebih seperti piring.

Adapun dalam penelitian ini teknik melempar yang dimaksud adalah teknik melempar bola kecil yang terdapat pada permainan kasti dan rounders. Sedangkan teknik melempar yang digunakan masih berhubungan dengan teknik yang digunakan pada cabang atletik.

\section{Model Kooperatif Tipe Snowball Throwing}

Snowball secara etimologi berarti bola salju, sedangkan throwing artinya melempar. Snowball Throwing secara keseluruhan dapat diartikan melempar bola salju. Dalam pembelajaran Snowball Throwing, bola salju merupakan kertas yang berisi pertanyaan yang dibuat oleh siswa 
kemudiandilempar kepada temannya sendiri untuk dijawab. Menurut Bayor (2010), Snowball Throwing merupakan salah satu model pembelajaran aktif (activelearning) yang dalam pelaksanaannya banyak melibatkan siswa. Peran guru di sini hanya sebagaipemberi arahan awal mengenai topik pembelajaran dan selanjutnya penertiban terhadap jalannya pembelajaran.

Menurut Saminanto (2010:37) "Metode Pembelajaran Snowball Throwing disebut juga metode pembelajaran gelundungan bola salju". Metode pembelajaran ini melatih siswa untuk lebih tanggap menerima pesan dari siswa lain dalam bentuk bola salju yang terbuat dari kertas, dan menyampaikan pesan tersebut kepada temannya dalam satu kelompok. Snowball Throwing adalah paradigma pembelajaran efektif yang merupakan rekomendasi UNESCO, yakni: belajar mengetahui (learning to know), belajar bekerja (learning to do), belajar hidup bersama (learning to live together), dan belajar menjadi diri sendiri (learning to be) (Depdiknas, 2001:5).

Snowball Throwing adalah suatu metode pembelajaran yang diawali dengan pembentukan kelompok yang diwakili ketua kelompok untuk mendapat tugas dari guru kemudian masing-masing siswa membuat pertanyaan yang dibentuk seperti bola (kertas pertanyaan) lalu dilempar ke siswa lain yang masing-masing siswa menjawab pertanyaan dari bola yang diperoleh. (Rahman, 2017: 3).

Metode pembelajaran Snowball Throwing adalah suatu metode pembelajaran yang diawali dengan pembentukan kelompok yang diwakili ketua kelompok untuk mendapat tugas dari guru kemudian masing-masing siswa membuat pertanyaan yang dibentuk seperti bola (kertas pertanyaan) lalu dilempar ke siswa lain yang masing-masing siswa menjawab pertanyaan dari bola yang diperoleh (Kisworo, dalam Mukhtari, 2010: 6). Model Pembelajaran Snowball Throwing adalah suatu tipe Model Kooperatif. Model pembelajaran ini menggali potensi kepemimpinan murid dalam kelompok dan keterampilan membuat-menjawab pertanyaan yang di padukan melalui permainan imajinatif membentuk dan melempar bola salju (Komalasari: 2010). Menurut Suprijono (2009:128) dan Saminanto (2010:37), langkah-langkah pembelajaran model Kooperatif tipe Snowball Throwing adalah:

1. Guru menyampaikan materi yang akan disajikan, dan KD yang ingin dicapai.

2. Guru membentuk siswa berkelompok, lalu memanggil masing-masing ketua kelompok untuk memberikan penjelasan tentang materi.

3. Masing-masing ketua kelompok kembali ke kelompoknya masing-masing, kemudian menjelaskan materi yang disampaikan oleh guru kepada temannya.

4. Kemudian masing-masing siswa diberikan satu lembar kertas kerja, untuk menuliskan satu pertanyaan apa saja yang menyangkut materi yang sudah dijelaskan oleh ketua kelompok.

5. Kemudian kertas yang berisi pertanyaan tersebut dibuat seperti bola dan dilempar dari satu siswa ke siswa yang lain selama \pm 5 menit.

6. Setelah siswa dapat satu bola/satu pertanyaan diberikan kesempatan kepada siswa untuk menjawab pertanyaan yang tertulis dalam kertas berbentuk bola tersebut secara bergantian.

7. Evaluasi 


\section{Penutup}

\section{METODE}

\section{Setting Penelitian}

Jenis penelitian yang dilakukan oleh peneliti yaitu penelitian tindakan kelas, yang lazim disebut PTK. Dengan demikian, penelitian ini sifatnya berbasis kelas, karena dilakukan dengan melibatkan komponen yang terdapat di dalam proses belajar mengajar di dalam kelas, materi pelajaran, dan metode pembelajaran

Empat tahapan digunakan secara sistematis dalam proses penelitian ini, dan diterapkan dalam dua siklus, yaitu proses tindakan siklus I dan proses tindakan siklus II. Namun dalam hal ini, peneliti memerlukan kajian awal berupa renungan atau refleksi awal sebagai studi pendahuluan sebelum melakukan perencanaan penelitian. Hal ini dimaksudkan untuk mengetahui semua gejala atau informasi tentang situasi-situasi yang relevan dengan topik penelitian.

\section{Subyek Penelitian}

Penelitian ini dilaksanakan oleh penulis di SD Negeri Wonokusumo VI/45 Kecamatan Semampir Kota Surabaya. Pelaksanaan penelitian dan perbaikan dijadwalkan oleh penulis dengan jadwal sebagai berikut:

Tabel 1. Waktu Pelaksanaan

\begin{tabular}{|l|l|c|c|c|}
\hline No & \multicolumn{1}{|c|}{ Jenis Kegiatan } & Agt & Sep & Okt \\
\hline 1 & Konsultasi dengan Kepala Sekolah. & M1 & & \\
\hline 2 & Mengajukan proposal penelitian. & M1 & & \\
\hline 3 & Mengajukan RPP & M2 & & \\
\hline 4 & Revisi RPP. & M3 & & \\
\hline 5 & Evaluasi kualitas RPP tahap akhir. & M4 & & \\
\hline 6 & Konsultasi dengan Observer. & M4 & M1-4 & \\
\hline 7 & Pelaksanaan siklus I. & & M1-4 & \\
\hline 8 & Pelaksanaan siklus II. & & M1-4 & \\
\hline 9 & Menyusun laporan tindakan. & & & M1-3 \\
\hline
\end{tabular}

Kelas yang dijadikan obyek perbaikan dan penelitian adalah kelas 3-A dengan jumlah siswa sebanyak 35 siswa.

\section{Teknik Pengumpulan Data}

Adapun teknik pengumpulan data yang penulis gunakan dalam penelitian ini adalah teknik nontes dan teknik tes. Teknik nontes alat penilaian yang dipergunakan untuk mendapatkan informasi tentang keadaan di tertes (testi, tercoba, inggris testee) tanpa dengan alat tes. Teknik nontes diperlukan untuk mendapatkan data yang tidak, atau paling tidak secara langsung, berkaitan dengan laku kognitif. Teknik ini diterapkan melalui kegiatan observasi dan pengumpulan dokumentasi. 


\section{Validasi Data}

Untuk mendapatkan data yang mendukung dan sesuai dengan karakteristik fokus permasalahan dan tujuan penelitian, teknik validasi yang digunakan dalam penelitian ini adalah audit trail. triangulasi data. Triangulasi data yaitu mengecek keabsahan (validasi) data dengan mengkonfirmasikan data yang sama dari sumber yang berbeda untuk memastikan keabsahan (derajat kepercayaan). Dari guru dilakukan pada saat pelaksanaan kegiatan inquiry learning balikan refleksi setelah pelaksanaan tindakan dan dengan data yang dijaring melalui lembar observasi teman guru/sejawat dan kepala sekolah. Sedangkan dari siswa dilakukan kuesioner atau wawancara. Dari ahli dilakukan pada saat bimbingan mengenai temuan-temuan penelitian dan penyusunan laporan.

\section{Teknik Analisa Data}

Pengumpulan data yang ada, selanjutnya dianalisis. Untuk menganalisis data tersebut, penulis memerlukan analisis data yang sesuai agar data yang diperoleh dapat dipertanggungjawabkan, maka dalam penelitian ini penulis menggunakan analisis data kualitatif dan analisis data kuantitatif.

Analisis data kualitatif pada penelitian ini diperoleh dari hasil observasi yang dilakukan oleh penulis yang memuat gambaran tingkat pengetahuan siswa terhadap suatu mata pelajaran, aktivitas dan antusiasme siswa saat mengikuti pelajaran setiap siklus.

Analisis data kuantitatif diperoleh dari hasil tes siswa yang bertujuan untuk mengetahui pengetahuan siswa tentang materi pelajaran dari setiap siklus, di mana siswa secara individu telah belajar tuntas atau berhasil apabila sekurang-kurangnya mendapat nilai 2,6 (nilai konversi dari nilai 65 dengan perbandingan nilai terbesar 4:100) berdasarkan kartu yang dipegangnya melalui model Kooperatif tipe Snowball Throwing. Standar penentuan ketuntasan belajar siswa menurut Sudjana (2006:109) sebagai berikut:

$$
\mathrm{P}=\sum_{\mathrm{N}}^{\sum \mathrm{f}} \mathrm{x} 100 \%
$$

Keterangan:

$\mathrm{P} \quad$ : Persentase ketuntasan secara individu.

$\sum \mathrm{f} \quad: \quad$ Jumlah nilai yang diperoleh siswa.

$\mathrm{N} \quad$ : Nilai maksimal.

Data pengamatan dianalisis dengan menghitung rata-rata pada setiap siklus yang dilaksanakan, selanjutnya nilai rata-rata tersebut diklasifikasikan dengan kriteria sebagai berikut:

$\begin{array}{ll}76-100 & : \text { Sangat baik } \\ 66-75 & : \text { Baik } \\ 46-65 & : \text { Cukup } \\ 0-45 & : \text { Kurang }\end{array}$

\section{Indikator Kinerja}

Indikator kinerja dalam penelitian ini sebagaimana terinci dalam tabel berikut: 
Tabel 2. Indikator Aktivitas Guru

\begin{tabular}{|c|c|}
\hline Aspek & Skor Maksimal \\
\hline Tema dan amanat & 10 \\
\hline Tokoh dan penokohan & 20 \\
\hline Alur & 20 \\
\hline Latar & 10 \\
\hline Diksi dan gaya bahasa & 10 \\
\hline Sudut pandang & 10 \\
\hline $\begin{array}{l}\text { Kepaduan unsur-unsur pembangun } \\
\text { cerpen }\end{array}$ & 20 \\
\hline Jumlah & 100 \\
\hline
\end{tabular}

Tabel 2. Indikator Aktivitas Guru

\begin{tabular}{|c|l|}
\hline No & Indikator aktivitas guru dalam model Kooperatif tipe Snowball Throwing \\
\hline 1 & Mengajukan permasalahan \\
\hline 2 & Mendiskusikan cara menjawab permasalahan yang diajukan \\
\hline 3 & Mengakomodasi kegiatan siswa dalam mencari jawaban secara berpasangan \\
\hline 4 & Memberi kesempatan bagi siswa untuk menyampaikan jawaban secara bergilir \\
\hline 5 & Mengevaluasi hasil jawaban \\
\hline
\end{tabular}

Tabel 3. Indikator Aktivitas Siswa

\begin{tabular}{|c|l|}
\hline No & \multicolumn{1}{|c|}{ Indikator aktivitas siswa dalam model Kooperatif tipe Snowball Throwing } \\
\hline 1 & Memahami permasalahan yang diajukan \\
\hline 2 & Memikirkan dan menuliskan jawaban atas permasalahan yang diajukan \\
\hline 3 & Mendiskusikan jawaban secara berpasangan \\
\hline 4 & Menyampaikan jawaban secara bergilir \\
\hline 5 & Mengevaluasi hasil jawaban \\
\hline
\end{tabular}

\section{HASIL DAN DISKUSI}

\section{Deskripsi Siklus I}

Pembelajaran pada siklus I dilaksanakan dalam waktu 2 × 2 × 25 menit. Pertemuan siklus I direncanakan pada hari Jum'at, tanggal 9 dan 16 September 2021, jam pelajaran 1 sampai dengan 2. Kegiatan pembelajaran yang dilakukan ini sesuai dengan langkah-langkah model Kooperatif tipe Snowball Throwing sebagai berikut:

1. Guru menyampaikan materi yang akan disajikan, dan KD yang ingin dicapai.

2. Guru membentuk siswa berkelompok, lalu memanggil masing-masing ketua kelompok untuk memberikan penjelasan tentang materi.

3. Masing-masing ketua kelompok kembali ke kelompoknya masing-masing, kemudian menjelaskan materi yang disampaikan oleh guru kepada temannya.

4. Kemudian masing-masing siswa diberikan satu lembar kertas kerja, untuk menuliskan satu pertanyaan apa saja yang menyangkut materi yang sudah dijelaskan oleh ketua kelompok.

5. Kemudian kertas yang berisi pertanyaan tersebut dibuat seperti bola dan dilempar dari satu siswa ke siswa yang lain selama \pm 5 menit. 
6. Setelah siswa dapat satu bola/satu pertanyaan diberikan kesempatan kepada siswa untuk menjawab pertanyaan yang tertulis dalam kertas berbentuk bola tersebut secara bergantian.

7. Evaluasi

8. Penutup

Penilaian observer tentang Aktivitas Guru pada Siklus I termasuk dalam kategori baik. Hal ini terlihat pada tahap pembelajaran kegiatan awal. Hal ini dipengaruhi oleh kemampuan guru dalam memotivasi siswa. Pada tahap kegiatan inti guru masih belum bisa melakukan improvisasi dan belum mengerti tentang langkah-langkah penyelesaian dalam pemecahan. Maka dari tinjauan ini, observer menyimpulkan bahwa pada tahap kegiatan Siklus I, tampaknya guru masih perlu bimbingan dalam hal mengimprovisasi langkah demi langkah dari metode yang digunakan.

Berdasarkan hasil analisa pada hasil belajar siswa dapat disimpulkan bahwa pada siklus I ratarata nilai hasil belajar Materi Memahami Teknik Melempar Bola pada siswa adalah 71,5 dan rata-rata kemampuan siswa dalam melaksanakan model Kooperatif tipe Snowball Throwing adalah 13,9 atau 69\%. Hal ini bila diinterpretasikan ke dalam tabel interpretasi dengan rata-rata 71,5 maka termasuk ke dalam kategori baik. Adapun ketuntasan klasikal pada siklus I sebesar 54\% dengan kategori cukup. Selain bagi siswa, model Kooperatif tipe Snowball Throwing ini merupakan hal yang baru bagi penulis sehingga sempat agak bingung bagaimana cara menjelaskan aturan pelaksanaannya pada siswa. Di samping itu, penulis sempat meragukan apakah dengan model dan model pembelajaran ini hasil belajar Materi Memahami Teknik Melempar Bola pada siswa berubah.

\section{Deskripsi Siklus II}

Pembelajaran pada siklus II dilaksanakan dalam waktu 2 × 2 × 25 menit. Pertemuan siklus II direncanakan pada hari Jum'at, tanggal 23 dan 30 September 2021, jam pelajaran 1 sampai dengan 2. Kegiatan pembelajaran yang dilakukan ini sesuai dengan langkah-langkah model Kooperatif tipe Snowball Throwing sebagai berikut:

1. Guru menyampaikan materi yang akan disajikan, dan KD yang ingin dicapai.

2. Guru membentuk siswa berkelompok, lalu memanggil masing-masing ketua kelompok untuk memberikan penjelasan tentang materi.

3. Masing-masing ketua kelompok kembali ke kelompoknya masing-masing, kemudian menjelaskan materi yang disampaikan oleh guru kepada temannya.

4. Kemudian masing-masing siswa diberikan satu lembar kertas kerja, untuk menuliskan satu pertanyaan apa saja yang menyangkut materi yang sudah dijelaskan oleh ketua kelompok.

5. Kemudian kertas yang berisi pertanyaan tersebut dibuat seperti bola dan dilempar dari satu siswa ke siswa yang lain selama \pm 5 menit.

6. Setelah siswa dapat satu bola/satu pertanyaan diberikan kesempatan kepada siswa untuk menjawab pertanyaan yang tertulis dalam kertas berbentuk bola tersebut secara bergantian.

7. Evaluasi

8. Penutup 
Penilaian observer tentang Aktivitas Guru pada Siklus II termasuk dalam kategori sangat baik. Hal ini terlihat pada tahap pembelajaran kegiatan awal. Hal ini dipengaruhi oleh kepandaian guru dalam memotivasi siswa. Pada tahap kegiatan inti guru telah berhasil melakukan improvisasi pada langkahlangkah penyelesaian. Maka dari tinjauan ini, observer menyimpulkan bahwa pada tahap kegiatan Siklus II secara global berjalan dengan lancar. Berdasarkan hasil analisa terhadap hasil belajar siswa dapat disimpulkan bahwa pada siklus II rata-rata nilai hasil belajar Materi Memahami Teknik Melempar Bola pada siswa adalah 78,1 dan rata-rata kemampuan siswa dalam melaksanakan model Kooperatif tipe Snowball Throwing adalah 15,3 atau 76\%. Hal ini bila diinterpretasikan ke dalam tabel interpretasi dengan rata-rata 78,1 maka termasuk ke dalam kategori baik. Adapun ketuntasan klasikal pada siklus II sebesar $83 \%$ dengan kategori sangat baik. Selain bagi siswa, model Kooperatif tipe Snowball Throwing ini merupakan hal yang menyenangkan bagi penulis sehingga pembelajaran menjadi hidup dan aktivitas siswa dalam belajar semakin meningkat. Model Kooperatif tipe Snowball Throwing ini harus dilaksanakan secara berkesinambungan sebagai upaya pembiasaan bagi siswa

\section{Diskusi}

Dengan demikian penerapan model Kooperatif tipe Snowball Throwing memiliki efektifitas untuk meningkatkan nilai autentik dan hasil belajar Materi Memahami Teknik Melempar Bola pada siswa. Hal ini terlihat dari tanjakan persentase hasil belajar Materi Memahami Teknik Melempar Bola pada siswa dari sebelum diterapkan model pembelajaran ini yang hanya memiliki rata-rata 53,9 menjadi 71,5 pada siklus I dan 78,1 pada siklus II.

Peningkatan kemampuan siswa dalam melaksanakan model Kooperatif tipe Snowball Throwing sebesar $24 \%$ dari dua siklus ini jika ditelusuri lebih dalam adalah karena adanya faktor motivasi dari dalam diri siswa itu sendiri, apakah mereka mau menunjukkan seluruh aktivitas belajar yang menjadi indikator penelitian sepenuh hati mereka atau tidak. Model dan model pembelajaran yang diterapkan hanyalah faktor stimulus untuk memunculkan pembiasaan pada diri siswa. Anggapan penulis ini tentu saja masih perlu dibuktikan dengan penelitian tindakan kelas lanjutan dari penelitian ini tiga atau empat bulan ke depan untuk menilai apakah pembiasaan dengan penggunaan model dan model pembelajaran tertentu memiliki signifikansi yang besar terhadap peningkatan hasil belajar Materi Memahami Teknik Melempar Bola pada siswa.

\section{KESIMPULAN}

Berdasarkan paparan hasil penelitian dan pembahasan, dapat dirumuskan kesimpulan penelitian bahwa ada peningkatan hasil belajar Materi Memahami Teknik Melempar Bola melalui penerapan model Kooperatif tipe Snowball Throwing pada siswa kelas 3-A SD Negeri Wonokusumo IV/43 Surabaya. Peningkatan hasil belajar Materi Memahami Teknik Melempar Bola melalui penerapan model Kooperatif tipe Snowball Throwing pada siswa kelas 3-A SD Negeri Wonokusumo IV/43 Surabaya rata-rata sebesar $24 \%$. 
Penerapan model pembelajaran Snowball Throwing merupakan salah satu wujud aplikasi pembelajaran bermakna dalam Materi Memahami Teknik Melempar Bola. Melalui model pembelajaran Snowball Throwing, siswa dilibatkan secara holistik baik aspek fisik, emosional, dan intelektualnya. Serangkaian kegiatan penerapan model Kooperatif tipe Snowball Throwing merupakan refleksi dari sistem Tandur yakni Tumbuhkan (memberikan apersepsi), Alami (menjawab pertanyaan yang diajarkan), Namai (menyimpulkan materi), Demostrasikan (melakukan Snowball Throwing), Ulangi (merangkum materi dalam pembelajaran), dan Rayakan (memberi reward). Dari hasil kesimpulan maka penulis sampaikan bahwa penerapan model Kooperatif tipe Snowball Throwing ini dapat meningkatkan hasil belajar Materi Memahami Teknik Melempar Bola pada siswa dan membutuhkan langkah tindak lanjut dan pembiasaan agar terbentuk karakter yang baik pada diri siswa agar kelak berguna bagi bangsa, negara dan agamanya.

Berdasarkan simpulan hasil penelitian tersebut, peneliti memberikan saran agar Agar persepsi negatif siswa terhadap suasana proses belajar mengajar yang menjenuhkan segera berubah, Guru Kelas harus kreatif dengan menerapkan berbagai model dan model pembelajaran yang PAKEMIP. Guru PJOK seyogyanya sering memberi peluang kepada siswanya untuk berkomunikasi antarteman, guru dan masyarakat sekolah, tentang materi ajar. Orang tua harus turut dilibatkan dalam rangka meningkatkan hasil belajar Materi Memahami Teknik Melempar Bola pada siswa karena bagaimanapun juga $83 \%$ waktu sehari semalam siswa dihabiskan di luar sekolah yang sepenuhnya adalah tanggung jawab orang tua.

\section{UCAPAN TERIMA KASIH}

Terimakasih kami ucapkan kepada Bapak/Ibu Kepala Sekolah dan Guru-guru di SDN Wonokusumo IV/43 Surabaya yang telah memberikan kesempatan kepada peneliti dalam melaksanakan penelitian. Selain itu tidak lupa rasa terimakasih pada peserta didik yang telah ikut berpartisipasi dalam melaksanakan penelitian ini.

\section{REFERENSI}

Bayor, A. (2010). Snowball Throwing. [Online]. Tersedia: http://akmaldebayor.blogspot.com/2010/05/snowball-throwing_08.html. [10-14-2021]

Depdiknas. 2006. Kurikulum Tingkat satuan Pendidikan (KTSP) untuk Sekolah Dasar/ MI. Jakarta: Depdiknas.

Komalasari, Kokom. (2010). Pembelajaran Kontekstual Konsep dan Aplikasi. Bandung: PT. Refika Aditama.

Mukhtari. 2010. Penerapan Metode Pembelajaran Snowball Throwing Dengan Penilaian Portofolio dalam Upaya Untuk Meningkatkan Pemahaman Materi Segitiga Siswa Kelas VII A Smp Islam 02 Pujon Tahun Pelajaran 2007/2008. Jurnal pendidikan. Vol 2, No. 1 
Rahman. 2017. Penerapan Snowball Throwing untuk meningkatkan hasil Belajar IPS Siswa Kelas V Pada SDN No. Pantobete: jurnal kreatif online. Volume 5, No 4.

Saminanto. 2010. Ayo Praktik PTK (Penelitian Tindakan Kelas). Semarang: Rasail Media Group. Sudjana, Nana.2006. Penilaian hasil belajar proses belajar mengajar. Bandung: Remaja Rosdakarya. 